\title{
ANALISIS TITIK IMPAS UNTUK MENCIPTAKAN EFISIENSI PRODUKSI USAHA TANI MELON DI KECAMATAN PRAYA TIMUR KABUPATEN LOMBOK TENGAH
}

\author{
Karjono $^{1^{*}}$ \\ ${ }^{1}$ Dinas Pertanian dan Tanaman Pangan Lombok Tengah ,karjono@gmail.com
}

\section{INFO ARTIKEL}

RiwayatArtikel:

Diterima: 17 -07-2017

Disetujui: 20-08-2017

\section{Kata Kunci:}

Efisiensi

Produksi

Titik Impas

\begin{abstract}
ABSTRAK
Abstrak: Tujuan dari penelitian ini adalah untuk mengetahui seberapa besar efisiensi produksi dan titik impas (Break Event Point) yang harus di penuhi untuk menciptakan usahatani melon di Kecamatan Praya TimurKabupaten Lombok Tengah. Metode penelitian menggunakan analisis deskriptif, unit analisis petani pengembang melon, jumlah responden 30 orang dengan quota sampling, dan metode pengumpulan data dengan wawancara dan dokumentasi.Hasil penelitian menunjukkan bahwa; (1). Besarnya penerimaan rata-rata petani pada usahatani Melon di Kecamatan Praya Timur sebesar Rp 9.356.40o sedangkan total biaya rata-rata yang di keluarkan selama proses produksi berlangsung adalah sebesar Rp 4.242.695 sehingga diperoleh pendapatan sebesar Rp 5.113.705. Tingkat Efisiensi produksi usahatani di analisis dengan menggunakan R/C ratio. Dari hasil perhitungan di peroleh R/C ratio sebesar 2,21 berarti bahwa usahatani Melon efisien untuk di usahakan (menguntungkan) atau tiap penambahan $\mathrm{Rp}$ 1,oo biaya yang di keluarkan akan menghasilkan penerimaan sebesar 2,21; dan (2). Sedangkan untuk nilai BEP (titik impas) untuk BEP volume produksi sebesar 2041,02 kg berarti apabila petani menghasilkan produksi di bawah $2041,02 \mathrm{~kg}$, maka petani akan mengalami kerugian. Untuk BEP harga di dapat rata-rata sebesar Rp 942,95 berarti apabila harga di tingkat petani di bawah Rp 942,95 per hektar, maka petani akan mengalami kerugian.
\end{abstract}

\section{A. LATAR BELAKANG}

Pertumbuhan ekonomi Indonesia pada Triwulan III-2012 yang digambarkan oleh Produk Domestik Bruto (PDB) menunjukkan peningkatan sebesar 6,17 persen. Berbeda dari sebelumnya Triwulan II-2012 meningkat hanya 3,21 persen dan pada Triwulan I-2012 meningkat hanya 2,8 persen. Peningkatan tertinggi terletak pada sektor pertanian dimana menyumbangkan 6,15 persen peningkatan. Berdasarkan data tersebut tentunya mengindikasikan bahwa sektor pertanian masih andalan untuk ditingkatkan dan dikembangkan [1].

Pengembangan pada sektor pertanian harus sinergi dengan komitmen pemerintah membangun system pertanian yang mandiri dan berkelanjutan. Selama ini pemerintah cenderung mengandalkan pembangunan pertanian pada subsektor tanaman pangan dan masih menomorduakan subsektor tanaman hortikultura sebagai salah satu sektor yang patut dipertimbangkan [2]

Bila melihat tujuan pembangunan pertanian maka intinya bertujuan meningkatkan kesejahteraan petani yang dapat dicapai melalui upaya peningkatan produksi, produktivitas dan pendapatan usahatani (baik subsektor tanaman pangan dan hortikultura).Berkaitan dengan tujuan tersebut dari pembangunan pertanian dari subsektor hortikultura telah ditetapkan kebijakan dalam pemilihan jenis tanaman pertanian tanaman hortikultura. Beberapa pedoman pemilihan jenis tanaman prioritas tersebut adalah sebagai berikut: a)
Bernilai ekonomi tinggi baik untuk konsumsi domestik maupun luar negeri; b) Memberikan kesempatan kerja yang lebih besar; c) Mempunyai prospek pasar dan pemasaran yang baik; d) Meningkatkan gizi masyarakat [3].

Komoditi hortikultura merupakan produk yang prospektif, baik untuk memenuhi kebutuhan pasar domestik maupun internasional.Permintaan pasar baik di dalam maupun di luar negeri masih besar. Hal ini terlihat berdasarkan data Departemen Perdagangan Per Januari - Mei 2012, nilai ekspor untuk tanaman hortikultura berupa buah-buahan sebesar 175,3 juta ton meningkat sebesar 26,6 juta ton dari tahun 2011 yang hanya sebesar 148,7 juta ton [4].

Di samping itu, produk ini juga memiliki nilai ekonomi yang tinggi.Kemajuan perekonomian menyebabkan permintaan produk hortikultura semakin meningkat. Di sisi lain, keragaman karakteristik lahan, agroklimat serta sebaran wilayah yang luas memungkinkan wilayah Indonesia digunakan untuk pengembangan hortukultura tropis dan sub tropis.

Berdasarkan data dari Dirjen [5] komoditas unggulan daerah yang pengembangannya telah didukung melalui pendanaan APBN mencakup 29 komoditas yang tersebar di 90 kabupaten/kota. Melon merupakan salah satu komoditas yang dikembangkan.

Usahatani melon adalah jenis usahatani yang memenuhi syarat dan perlu mendapat perhatian dalam pengembangannya. Hal ini didasarkan pada kenyataan 
bahwa produk usahatani melon sangat digemari masyarakat baik sebagai buah segar maupun juice bahkan sebagai bahan baku industri minuman. Selain itu, harga buah melon yang relative tinggi dibanding komoditas sejenis merupakan peluang besar untuk peningkatan pendapatan dan kesejahteraan petani atau pengusaha usahatani melon [6].

Kabupaten Lombok Tengah menjadi salah satu daerah pertanian di Nusa Tenggara Barat yang mengusahakan agribisnis melon. Berdasarkan data 2010 produksi Melon di Lombok Tengah dimulai pada tahun 2009 dengan produktivitas sebesar $190 \mathrm{Kw} / \mathrm{Ha}$. Kemudianmeningkat sebesar $400 \mathrm{Kw} / \mathrm{Ha}$ pada tahun 2010.Begitu juga dengan lahan yang dimanfaatkan untuk produksi Melon meningkat sebesar $5 \mathrm{Ha}$ dari tahun sebelumnya.

Namun demikian perlu dilakukan analisis sisi hulunya apakah masih menunjukkan indikasi efisien atau tidak.Sebab dengan kondisi laju inflasi semacam ini tidak menutup kemungkinan masih mengarah pada situasi yang efisien. Oleh sebab itu efisiensi ini akan dilihat apakah dipengaruh oleh variabel-variabel independen yaitu alokasi input.

Berdasarkan realitas diatas maka telah dilakukan penelitian tentang "Analisis Titik Impas untuk Menciptakan Efisiensi Produksi Usahatani Melon di Kecamatan Praya Timur Kabupaten Lombok Tengah”.

\section{B. METODE PENELITIAN}

Penelitian ini menggunakan metode desriptif, yaitu suatu metode yang bertujuan untuk memecahkan masalah yang ada pada saat sekarang dengan cara mengumpulkan, menyusun, menganalisa, dan menginterpretasikan data, kemudian menarik suatu kesimpulan.

Unit analisis dalam penelitian ini adalah usahatani melon (khususnya Kecamatan Praya Timur) di Kabupaten Lombok Tengah.

Lokasi penelitian ini dilaksanakan di Kecamatan Praya Timur Kabupaten Lombok Tengah. Dari sepuluh Desa yang ada di Kecamatan Praya Timur ditetapkan satu Desa secara "Purposive Sampling" sebagai daerah penelitian yaitu Desa Ganti dengan pertimbangan bahwa Desa tersebut memiliki usahatani melon yang sudah berproduksi dan sudah di pasarkan.

Penentuan responden dalam penelitian ini dilakukan secara quota sampling yaitu dengan menetapkan sebanyak 30 responden petani melon di Desa Ganti Kecamatan Praya Timur.Metode pengumpulan data yang dipergunakan dalam penelitian ini dengan wawancara dan dokumentasi.

Analisis data dibagi menjadi 2; (1) menghitung efisiensi usahatani melon terlebih dahulu menghitung sarana produksi dan tenaga kerja selanjutnya menghitung $\mathrm{R} / \mathrm{C}$ rasio. Jika $\mathrm{R} / \mathrm{C}$ ratio $>1$, maka usahatani yang dilaksanakan efisien, jika $\mathrm{R} / \mathrm{C}$ ratio $=1$, maka usahatani yang dilaksanakan tidak untung dan tidak rugi, dan jika $\mathrm{R} / \mathrm{C}$ ratio $<1$, maka usahatani melon yang dilaksanakan tidak efisien; (2) mengitung BEP volume produksi dan BEP Harga, untuk BEP volume produksi jika BEP volume produksi > rata-rata produksi maka kategori rugi dan bila BEP volume produksi < rata-rata produksi maka kategori untung. Begitu juga sebaliknya untuk BEP harga.

\section{HASIL DAN PEMBAHASAN}

\section{Alokasi Penggunaan Faktor-Faktor Produksi}

Usahatani adalah suatu kegiatan mengusahakan dan mengkoordinir faktorfaktor produksi berupa lahan, tenaga kerja, dan modal sehingga memberikan manfaat sebaikbaiknya.Usahatani merupakan cara-cara petani menentukan, mengorganisasikan, dan mengkoordinasikan, penggunaan faktor-faktor produksi seefektif dan seefisien mungkin sehingga usaha tersebut memberikan pendapatan semaksimal mungkin [8].

Soekartawi (2001), mengemukakan bahwa yang dimaksud dengan faktor produksi adalah semua korbanan yang diberikan pada tanaman agar tanaman tersebut mampu tumbuh dan menghasilkan dengan baik. Faktor produksi dikenal pula dengan istilah input dan korbanan produksi. Faktor produksi memang sangat menentukan besar-kecilnya produksi yang diperoleh.Faktor produksi lahan, modal untuk membeli bibit, pupuk, obat-obatan dan tenaga kerja dan aspek manajemen adalah faktor produksi yang terpenting. Hubungan antara faktor produksi (input) dan produksi (output) biasanya disebut dengan fungsi produksi atau faktor relationship.

Usahatani melon yang dilakukan oleh petani responden mempunyai tujuan utama yaitu untuk mendapatkan pendapatan yang maksimal dengan menggunakan faktor produksi seoptimal mungkin.Didalam usahatani melon ini rekapitulasi biaya yang di keluarkan harus di perhitungkan sebagai biaya oleh pengelola usahatani, karena dengan di ketahui biaya dan penerimaan seorang petani dapat memperkirakan apakah usahatani yang dilakukan untung atau rugi.

Adapun biaya dari usahatani dapat dicapai secara minimal untuk menghasilkan pendapatan yang cukup untuk mengembalikan modal, baik pinjaman atau biaya lain. Setiap melakukan usahatani selalu memerlukan usahatani di antaranya adalah pupuk, bibit, obat - obatan dan lain sebagainya.Menurut [7] 
bahwa biaya usahatani digolongkan menjadi dua yaitu biaya tetap dan biaya tidak tetap.

a. Biaya Tetap

Biaya tetap adalah biaya yangdi keluarkan oleh petani yang besar kecilnya tidak mempengaruhi terhadap hasil produknya nanti.Biaya ini terdiri dari biaya sewa tanah dan pajak serta biaya peralatan, biaya produksi yang pemakaiannya lebih.

b. Biaya Sewa Tanah

Dalam perhitungan biaya sewa tanah di Kabupaten Lombok Tengah pada musim tanam tahun 2012 rata-rata sebesar Rp 4.000.000 untuk tiap musim. Untuk biaya sewa yang ada dari 30 responden dalam usaha tani melon di Desa Ganti dapat di ambil rata-rata sebesar Rp 8.004.191.

c. Biaya Penyusutan

Biaya peralatan perhitungan tidak dimasukkan dalam perhitungan, karena alat- alat pertanian itu tahan lama dan dapat digunakan pada beberapa kali proses produksi, sehingga nilai penyusutannya kecil dan diabaikan.

\section{d. Biaya Variabel}

Biaya variable atau biaya tidak tetap adalah biaya yang besar kecilnya akan berpengaruh terhadap hasil produksinya. Biaya tidak tetap meliputi biaya bibit, biaya pengobatan, biaya tenaga kerja.

1. Biaya Sarana Produksi

Biaya sarana produksi adalah biaya variable dimana di dalam biaya tersebut dapat habis dalam satu kali proses produksi. Adapun yang termasuk biaya sarana produksi meliputi biayabibit, pupuk, dan obat-obatan. Penggunaan biaya sarana produksi terdapat pada tabel berikut :

Tabel 1.

Rata-Rata Pengeluaran Biaya Sarana Produksi Pada Usahatani Melon

\begin{tabular}{|c|c|c|c|c|c|}
\hline No & Faktor Produksi & Fisik & Harga (Rp) & Nilai (Rp) & Prosentase \\
\hline 1 & Bibit (Kg) & 12,80 & 130.000 & 1.664 .000 & 54,66 \\
\hline 2 & TSP (Kg) & 164,57 & 2.000 & 329.133 & 10,81 \\
\hline 3 & KCL (Kg) & 101,00 & 2.000 & 202.000 & 6,63 \\
\hline 4 & $\mathrm{ZA}(\mathrm{Kg})$ & 105,83 & 1.500 & 158.750 & 5,21 \\
\hline 5 & Kandang (Kg) & $1.002,87$ & 400 & 401.146 & 13,17 \\
\hline 6 & Antracol (Kg) & 1,18 & 100.000 & 118.000 & 3,87 \\
\hline 7 & Green Tonic (Kg) & 1,18 & 75.000 & 88.750 & 2,91 \\
\hline 8 & Trisula (Kg) & 0,92 & 90.000 & 82.500 & 2,71 \\
\hline & Jumlah & $1.390,35$ & 400900 & 3.044 .029 & 100 \\
\hline
\end{tabular}

Sumber : Diolah dari data primer

Penggunaan bibit di daerah penelitian menunjukkan $12,8 \mathrm{Kg} / \mathrm{Ha}$ atau sekitar $54,66 \%$ dari jumlah penggunaan faktor produksi. Dimana penggunaan bibit sudah sesuai dengan rekomendasiyang di anjurkan dari penyuluh yaitu sebesar $13 \mathrm{~kg}$ per hektar.Dan bibit masih menunjukkan prosentase yang paling tinggi.

Untuk penggunaan pupuk di daerah penelitian penggunaan pupuk TSP sebanyak $164,57 \mathrm{Kg}(10,81 \%)$, Pupuk KCL sebanyak 101 Kg (6,63\%), Pupuk ZA sebanyak 105,83 Kg (5,21\%), dan Pupuk Kandang sebanyak 1002,87 Kg (13,17\%). Dari keempat jenis pupuk tersebut yang paling banyak penggunaannya adalah pupuk TSP. Dan penggunaan pupuk paling sedikit adalah ZA jadi total biaya yang di keluarkan petani untuk biaya sarana produksi pupuk sebesar Rp 1.091.029 per hektar.

Untuk penggunaan pestisida atau obatobatan pada usahatani melon rata-rata petani membutuhkan $3.28 \mathrm{Kg}$ sedangkan anjuran rekomendasi yang tepat adalah sangat tergantung dari adanya intensitas serangan hama dan penyakit pada tanaman melon di daerah penelitian. Maka total biaya yang di keluarkan untuk obat-obatan sebesar Rp 289.250.

2. Biaya Tenaga Kerja

Tenaga kerja untuk usahatani ini dapat berasal dari dalam keluarga dan luar Keluarga.Curahan tenaga kerja yang di perhitungkan adalah biaya dari luar keluarga.Satuan tenaga kerja yang digunakan adalah HKSP (hari kerja setara pria). Tabel di bawah ini akan menjelaskan penggunaan tenaga kerja untuk setiap hektar usahatani melon di Kecamatan Praya Timur Kabupaten Lombok Tengah selama satu musim tanam. 
Tabel 2

Rata-Rata Pengeluaran Biaya Tenaga Kerja Pada Usahatani Melon

\begin{tabular}{cccc}
\hline No & Jenis Biaya & Total Biaya (Rp) & Prosentase (\%) \\
\hline 1 & Pengolahan Tanah & $374.583,13$ & 31,25 \\
2 & Penanaman & $149.833,25$ & 12,5 \\
3 & Pemeliharaan & $299.666,50$ & 25 \\
4 & Pengobatan & $149.833,25$ & 12,5 \\
5 & Panen & $224.749,88$ & 18,75 \\
\hline
\end{tabular}

Sumber : Diolah dari data primer

Penggunaan tenaga kerja pada usahatani melon rata-rata per luas lahan menghabiskan biaya Rp 1.198.666. Dan pada Analisis biaya tenaga kerja ini yang banyak mengeluarkan biaya yaitu pada kegiatan pengolahan tanah sebesar Rp 374.583,13 (31,25\%), penanaman sebesar Rp 149.833,25 (12,50\%), pemeliharaan sebesar Rp 299.666,50 (25\%), pengobatan sebesar Rp 149.833,25 (12,50\%) serta panen sebesar 224.749,88 (18,75\%). Panen biasanya di lakukan serentak dalam satu hari sehingga di perlukan tenaga kerja yang cukup banyak e. Total Biaya Produksi

Total biaya produksi merupakan penjumlahan dari seluruh biaya yang di keluarkan dalam suatu proses produksi atau penjumlahan dari biaya tetap dan variabel. Biaya produksi itu sendiri meliputi biaya sewa tanah dalam hal ini petani responden tidak mengeluarkan biaya sewa lahan karena lahan yang digunakan untuk usahatani adalah milik sendiri, sarana produksi dan tenaga kerja.Total biaya produksi pada usaha tani melon dapat di lihat pada tabel berikut :

Tabel 3

Rata-Rata Biaya Produksi Usahatani Melon Di Kabupaten Lombok Tengah Jenis Biaya

Biaya Tidak Tetap (Variabel)

$\checkmark$ Sarana Produksi

Total Harga (Rp/Ha)

$\checkmark \quad$ Tenaga Kerja

3.044 .029

Jumlah

1.198 .666

Sumber : Diolah dari data primer

Selama proses produksi biaya yang di keluarkan oleh petani melon dari biaya tetap dan biaya variabel sebesar $\mathrm{Rp}$ 4.242.695 dalam satu kali musim di Kabupaten Lombok Tengah. Berdasarkan tabel di atas dapat di lihat bahwa dalam usaha tani melon memerlukan biaya cukup besar baik biaya tetap maupun biaya variabel dalam jangka waktu 3 bulan.

Tabel 4

Rata-Rata Pendapatan Usahatani Melon Di Daerah Penelitian

\begin{tabular}{|c|c|c|}
\hline No & Uraian & Nilai \\
\hline 1 & Penerimaan & 9.356 .400 \\
\hline & $\checkmark \quad$ Produksi (Kg) & 2.079 \\
\hline & $\checkmark \quad$ Harga (Rp) & 4.500 \\
\hline 2 & Biaya Produksi & 4.242 .695 \\
\hline 3 & Pendapatan & 5.113 .705 \\
\hline 4 & R/C Rasio & 2,21 \\
\hline
\end{tabular}

Sumber : Diolah dari data primer

Penerimaan yang di peroleh petani dan usahatani melon adalah sebesar Rp 9.356.400 yang mana penerimaan tersebut diperoleh dari hasil produksi sebanyak $2079 \mathrm{Kg}$, dengan harga tiap kilo adalah Rp. 450o. Harga tersebut diperoleh dengan cara mengambil harga rata-rata responden pada

\section{f. Pendapatan Usahatani}

Pendapatan usahatani adalah nilai penerimaan dikurangi dengan total biaya yang di keluarkan selama proses produksi yang dinyatakan dengan nilai uang. Dari hasil penelitian mengenai besarnya pendapatan usahatani melon dapat dilihat pada Tabel berikut : saat panen. Petani memperoleh pendapatan sebesar 5.113.705.Ketidakpastianharga diakibatkan tenggang waktu produksi yang di hadapi produsen yang terdapat hampir seluruh komoditi pertanian dan produksi pertanin yang memakan waktu.Jadi harga jual produksi terpengaruh terhadap 
pendapatan petani.Fluktuasi harga produksi melon tergantung pada faktor ikilim, suhu, serta struktur tanah yang berada di daerah tersebut.

\section{g. Efisiensi Produksi Usahatani Melon}

Efisiensi artinya sebagai upaya untuk mencapai tujuan dengan menggunakan seminimal mungkin atau menggunakan sumberdaya yang optimal untuk mencapai tujuan yang maksimal.Dalam penelitian usahatani melon ini dapat di ketahui efisien apabila nilai $\mathrm{R} / \mathrm{C}$ Ratio $>1$.

Adapun besarnya R/C Ratio pada usahatani melon di daerah penelitian adalah sebesar 2,21, yang berarti bahwa usahatani tersebut menguntungkan (efisien), dimana dapat di artikan bahwa setiap biaya produksi yang di keluarkan pada usahatani melon sebesar 1 maka akan memperoleh penerimaan sebesar Rp 2,21. Dan untuk menaikkan $\mathrm{R} / \mathrm{C}$ Ratio yaitu dengan menurunkan total biaya dengan cara menekan biaya tidak tetap dan biaya variabel. Untuk menekan biaya tidak tetap dapat dilakukan misalnya dengan memberdayakan tenaga kerja yang berasal dari keluarga. Sedang untuk menekan biaya variabel dapat di lakukan dengan mengganti pupuk atau obat-obatan yang mempunyai fungsi dan kegunaan yang sama tetapi mempunyai harga yang lebih murah.

\section{Titik Impas Volume Produksi dan Harga}

Dalam menjelaskan skala usahatani melon maka diperlukan pemahaman mendasar kaitannya dengan titik impas (Break Even Point) dan optimasi usahatani melon.Analisis Titik Impas (Break Even Point/BEP) adalah suatu teknik untuk mempelajari hubungan antara biaya tetap, biaya variabel, keuntungan dan volume produksi. Titik impas dapat diartikan sebagai titik atau keadaan dimana perusahaan di dalam menjalankan operasinya tidak untung dan tidak rugi, atau pada keadaan dimana keuntungan perusahaan sama dengan nol. Dalam penelitian ini BEP yang dianalisis yakni BEP volume produksi dengan BEP harga produksi.

BEP volume produksi diperoleh dari selisih antara total cost/total biaya (TC) dengan jumlah produksi (Q). Secara matematis diperoleh rumus sebagai berikut :

$$
\text { BEP Volume Produksi }=\frac{T C}{Q}
$$

BEP harga produksi diperoleh dari selisih antara total cost (total biaya) dengan harga (P). Secara matematis diperoleh rumus sebagai berikut :

$$
\text { BEP Harga Produksi }=\frac{T C}{P}
$$

Titik impas usahatani melon di Kabupaten Lombok Tengah sebagai berikut :

Tabel 5

Titik Impas Usahatani Melon di Kabupaten Lombok Tengah

\begin{tabular}{clc}
\hline No & Uraian & Nilai \\
\hline 1 & Rata-Rata Luas Lahan (ha) & 0,80 \\
2 & Rata-Rata Produktivitas (Kg/ha) & 2598.75 \\
3 & Rata-Rata Total Biaya (Rp) & 4.243 .280 \\
4 & Harga Melon 2012 (Rp/kg) & 4500 \\
5 & Rata-Rata Jumlah Produksi (Kg) & 2079 \\
6 & Titik Impas Volume Produksi (Kg/ha) & 2041,02 \\
7 & Titik Impas Harga Produksi (Rp/Kg) & 942,95 \\
8 & Titik Impas Luas Lahan (Rp/ha) & 0,785 \\
\hline
\end{tabular}

Sumber : diolah dari data primer

Berdasarkan tabel 5 menunjukkan bahwa BEP volume produksi (2041,02 kg), nilai tersebut lebih rendah dari rata-rata jumlah produksi di lokasi penelitian sebesar $2079 \mathrm{~kg}$. Artinya usahatani melon tidak mengalami kerugian hal ini karena produksi masih berada diatas titik impas, apabila ingin menurunkan lagi BEP volume produksi dapat dilakukan dengan cara meningkatkan harga ditingkat petani atau dengan menurunkan total biaya.

Selanjutnya BEP harga produksi (Rp. 942,95/Kg) menunjukkan nilai lebih kecil dari harga melon sebesar Rp. 4500/kg. Artinya harga melon ditingkat petani berada diatas nilai BEP harga produksi yang berarti usahatani melon menguntungkan. Untuk menurunkan BEP harga dapat dilakukan dengan cara menekan biaya total produksi atau dengan meningkatkan total produksi yang misalnya dengan menggunakan bibit uggul yang tahan terhadap hama dan penyakit atau dengan

\section{Harga (Rp)}

pemeliharaan secara intensif untuk mencegah resiko kegagalan.

Secara garis besar hubungan penerimaan biaya dan produksi yang dihasilkan digambarkan sebagai berikut :

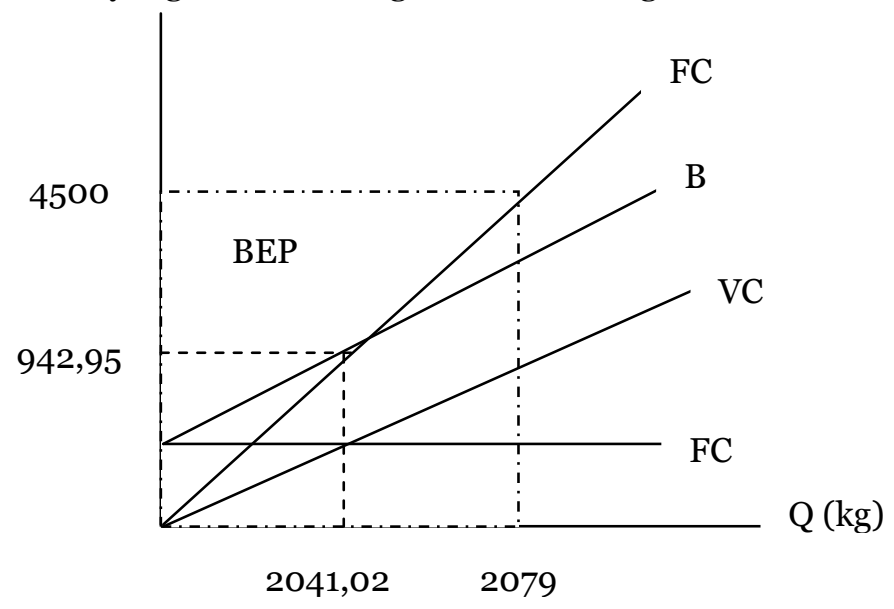


Gambar 1. Posisi Usahatani Melon di Lokasi Penelitian

Ketarangan :

$$
\begin{aligned}
& \mathrm{TC}=\text { Total } \text { Cost } \\
& \mathrm{TR}=\text { Total Revenue } \\
& \mathrm{BEP}=\text { Titik Impas }(\mathrm{TR}=\mathrm{TC}) \\
& \mathrm{VC}=\text { Variabel Cost }(\text { Biaya Variabel }) \\
& \mathrm{FC}=\text { Fixed Cost } \text { (Biaya Tetap) }
\end{aligned}
$$

Gambar 1 menunjukkan bahwa pada saat produksi 2041,02 kg maka terjadi BEP dimana seorang petani yang berada didaerah itu. Biaya yang dikeluarkan sama dengan biaya produksi yang dihasilkan, jadi petani tidak mengalami untung atau rugi. Dan harga Break Event Point (BEP) Rp 942,95/kg. dan apabila produksi berada di bawah 2041,02 kg dan bila harga dibawah $\mathrm{Rp}$ 942,95/kg petani akan mengalami kerugian, dimana biaya yang dikorbankan untuk faktor produksi lebih besar dari total penerimaan. Dan kenyataan di lapangan rata - rata produksi mencapai $2079 \mathrm{~kg}$ dengan harga di tingkat petani sebesar Rp. 4500. Jadi petani sudah mendapat keuntungan karena total penerimaan yang di peroleh petani lebih besar dari jumlah biaya yang dikeluarkan.

\section{SIMPULAN DAN SARAN}

\section{Simpulan}

Berdasarkan tujuan dan pembahasan yang terbatas pada penelitian ini maka dapat ditarik simpulan :

1. Penggunaan bibit di daerah penelitian menunjukkan $12,8 \mathrm{Kg} / \mathrm{Ha}$ atau sekitar 54,66\% dari jumlah penggunaan sarana produksi lain, penggunaan tenaga kerja menghabiskan biaya $\mathrm{Rp}$ 1.198.666. untuk kegiatan pengolahan tanah sebesar Rp 374.583,13 atau 31,25\% paling besar dari kegiatan lain, dan $\mathrm{R} / \mathrm{C}$ rasio usahatani melon dilokasi penelitian sebesar 2,21.

2. BEP volume produksi $(2041,02 \mathrm{Kg} / \mathrm{ha})$ dan BEP harga produksi $(942,95 \mathrm{Rp} / \mathrm{Kg})$ menunjukkan nilai lebih besar dari rata-rata produksi dan rata-rata harga melon. Artinya usahatani melon di Kabupaten Lombok Tengah sangat menguntungkan.

\section{Saran}

Untuk menumbuhkan motivasi dalam berusaha dibutuhkan waktu lama dan memberikan rangsangan, misalnya dalam bentuk peminjaman modal, menyediakan sarana dan prasarana, penyuluhan yang intensif, sehingga akan dapat meningkatkan motivasi petani dalam meningkatkan produksi. Selanjutnya bagi petani diharapkan untuk mencari informasi harga dan tidak terlambat dalam responnya agar disaat panen tidak mengalami kerugian.

\section{DAFTAR RUJUKAN}

[1] Biro Pusat Statistik, 2012. Berita Resmi Statistik No. 73/11/Th. XV, 5 November 2012.

[2]Oktavio. N., 2012. Lima Masalah Yang Membelit Pembangunan Pertanian di Indonesia. Diambil dari www.setkab.go.id

[3] Tjahjadi, N., 1996. Bertanam Melon. Penebar Swadaya. Jakarta

[4] Departemen Perdagangan, 2012. Data Ekspor Non-Migas Utama Menurut Komoditi Per Januari - Mei 2012.

[5] Dirjen Hortikultura Departemen Pertanian, 2009. Statistik Pertanian Nusa Tenggara Barat

[6] Rukmana, R., 2000. Budidaya, Pasca Panen danPenganekaragaman Pangan. Penerbit CV. Aneka Ilmu. Semarang;

[7] Sumodinigrat, G, 1993. Ekonomi Produksi, Karunika Jakarta, Universitas Terbuka.

[8] Suratiyah, 2006. Ekonomi Sumberdaya Alam dan Lingkungan: Suatu Pendekatan Teoritis. Yogyakarta 